\title{
ABOUT THE AUTHOR AND THE EDITORS
}

ROBERT S. HARTMAN was Research Professor of Philosophy at The University of Tennessee and at the National University of Mexico when he died on September 20,1973. He was buried near his home in Cuernavaca, Mexico. He was born in Berlin on January 27, 1910. He attended the German College of Political Science, the University of Paris, the London School of Economics, and Berlin University, where he received he LL.B. in 1932. For a brief period, he taught at Berlin University and served as an assistant district court judge.

Hartman's rejection of Fascism, which he expressed in speeches and articles, brought him into conflict with the Nazi party and forced him to leave Germany, using a fake passport, in 1932. He legally changed his name, which originally was Robert Schirokauer, to the name on his passport, Robert S. (for Schirokauer) Hartman. In 1938, using a Swedish alien's passport, he and his wife, the former Rita Emanuel, and son, Jan, left Europe for Mexico, where they lived until their immigration in 1941 to the United States, where they later became citizens.

Hartman's first teaching position in the United States was at Lake Forest Academy in Illinois. While there, he enrolled at Northwestern University where he received his $\mathrm{Ph} . \mathrm{D}$. in 1946. He taught at the College of Wooster in Ohio from 1945-1948, and at the Ohio State University from 1948-1956. He was a visiting professor at Massachusetts Institute of Technology, 19551956, and at Yale, 1966. He was Smith Mundt State Department Research Fellow and Exchange Professor at the National University of Mexico, 19561957. He held more than fifty lectureships in the United States, Canada, Latin America, and Europe. He was a research professor of philosophy at the National University of Mexico from 1957 until his death in 1973, and at The University of Tennessee from 1968-1973.

Hartman's formal axiology, as the ordering logic for the value sciences, was developed in many published articles and received its most complete expression in his major work, The Structure of Value: Foundations of Scientific Axiology (Carbondale and Edwardsville, Ill.: Southern Illinois University Press, 1967). In the field of psychology he applied formal axiology in "The Hartman Value Profile," a value test widely used in Mexico and by psychiatrists, psychologists, and business consultants in the United States.

Since Hartman's untimely death, his work has been carried on by members of the Robert S. Hartman Institute, composed of former colleagues, students, and many others who have been deeply influenced by the man and his thinking. Members of the Institute have posthumously published many of his writings, as well as critical studies and applications of his work. These include his autobiography, Freedom to Live: The Robert Hartman Story, ed. Arthur R. Ellis (Amsterdam-Atlanta: Editions Rodopi, 1994), and two books containing previously unpublished essays and contemporary critical reactions to his positions-Forms of Value and Valuation: Theory and Appli- 
cations, eds. Rem B. Edwards and John W. Davis (Lanham, Md.: University Press of America, 1991) and Formal Axiology and Its Critics, ed. Rem B. Edwards (Amsterdam-Atlanta: Editions Rodopi, 1995). Several other books based on Hartman's work have also been published in the Hartman Institute Studies in Axiology special series of the Value Inquiry Book Series.

ARTHUR R. ELLIS is a Licensed Professional Counselor who has been a clinician since 1971. He holds degrees in psychology (B.S.) and rehabilitation counseling (M.S.) from the University of Tennessee at Knoxville, and counseling (Ph.D.) from LaSalle University. Since 1976, he has worked in the Psychology Service of a Veterans Affairs Medical Center. He studied formal axiology under Robert S. Hartman, who personally trained him in the use and interpretation of the "Hartman Value Profile." His research has included explorations of the value patterns of alcoholics.

Dr. Ellis has been an active member of the Robert S. Hartman Institute for Formal and Applied Axiology, serving on the Board of Directors, holding the positions of Executive Director and President, and being recognized as a Fellow of the Institute. In 1994, Ellis edited Robert S. Hartman's autobiographical manuscript, Freedom to Live: The Robert Hartman Story, for publication.

Dr. Ellis is a Master Addictions Counselor, a Diplomate of the American Psychotherapy Association, and a Professional Member of the American Mental Health Counselors Association.

REM B. EDWARDS received his A.B. degree from Emory University in 1956, where he was elected to Phi Beta Kappa. During graduate school he was a Danforth Graduate Fellow. He received a B.D. degree from Yale University Divinity School in 1959 and a Ph.D. from Emory University in 1962. He taught for four years at Jacksonville University in Florida, moved from there to the University of Tennessee, Knoxville, in 1966, and retired from there partly in 1997 and partly in 1998 . He continues to be professionally active and kept an office on the University campus until the end of May, 2000. He was a U.T. Chancellor's Research Scholar in 1985 and a Lindsay Young Professor from 1987 to 1998.

His areas of specialization are Philosophy of Religion, American Philosophy, Ethical Theory, Medical Ethics with a special interest in Mental Health Care, Ethics and Animals, and Formal Axiology.

$\mathrm{He}$ is the author or editor of sixteen books, including Reason and Religion (New York: Harcourt, 1972 and Lanham, Md.: University Press of America, 1979); Pleasures and Pains: A Theory of Qualitative Hedonism (Ithaca, N. Y.: Cornell University Press, 1979); with Glenn Graber, BioEthics (San Diego: Harcourt, 1988); with John W. Davis, Forms of Value and Valuation: Theory and Applications (Lanham, Md.: University Press of America, 
1991); Formal Axiology and Its Critics (Amsterdam-Atlanta: Editions Rodopi, 1995); Violence, Neglect, and the Elderly, co-edited with Roy Cebik, Glenn Graber, and Frank H. Marsh (Greenwich, Conn.: JAI Press, 1996); New Essays on Abortion and Bioethics (Greenwich, Conn.: JAI Press, 1997); Ethics of Psychiatry: Insanity, Rational Autonomy, and Mental Health Care (Buffalo, N.Y.: Prometheus Books, 1997); Values, Ethics, and Alcoholism, co-edited with Wayne Shelton (Greenwich, Conn.: JAI Press, 1997); Bioethics for Medical Education, co-edited with Dr. Edward Bittar (Stamford, Conn.: JAI Press, 1999); Religious Values and Valuations (Chattanooga, Tenn.: Paidia Publishing Co, 2000); What Caused the Big Bang? (Amsterdam-New York: Editions Rodopi, 2001); and, with Thomas M. Dicken, Dialogues on Values and Centers of Value: Old Friends, New Thoughts (Amsterdam-New York: Editions Rodopi, 2001). Edwards is also the author of over sixty articles and reviews, including "How Process Theology Can Affirm Creation Ex Nihilo," Process Studies, 29:1 (2000), pp. 77-96.

He is an Associate Editor with the Value Inquiry Book Series, published by Editions Rodopi, where he is responsible for the Hartman Institute Axiological Studies special series. For a number of years he was co-editor of the Advances in Bioethics book series published by JAI Press.

Edwards has been the President of the Tennessee Philosophical Association (1973-1974), the Society for Philosophy of Religion (1981-1982), and the Southern Society for Philosophy and Psychology (1984-1985). He is a Charter Member and Fellow of the Robert S. Hartman Institute for Formal and Applied Axiology, has served on its Board of Directors since 1987, and since 1989 has been its Secretary-Treasurer. He chairs the committee that established and maintains the website for the Robert S. Hartman Institute at: http://www.hartmaninstitute.org 